\title{
An intersectional analysis of the revolutionary limits and potentialities of youtube videos from the anti-racist perspective of Rita Von Hunt on the "Tempero Drag" channel Título em inglês
}

\section{Uma análise interseccional dos limites e potencialidades revolucionárias de vídeos do youtube a partir da perspectiva antirracista de Rita Von Hunt no canal "Tempero Drag"}

\section{Un análisis interseccional de los límites y potencialidades revolucionarios de los videos de youtube desde la perspectiva antiracista de Rita Von Hunt en el canal "Tempero Drag"}

\author{
Ivanderson Pereira da Silva1 ${ }^{\text {(DD }}$, Mayara Teles Viveiros de Lira ${ }^{2}$ iD, \\ Lilian Kelly de Almeida Figueiredo Voss ${ }^{3}$ iD
}

\footnotetext{
${ }^{1}$ Universidade Federal de Alagoas, Arapiraca, Alagoas, Brasil.

2 Universidade Federal de Alagoas, Maceió, Alagoas, Brasil.

${ }^{3}$ Universidade Federal de Alagoas, Delmiro Gouveia, Alagoas, Brasil.
}

Autor correspondente:

Ivanderson Pereira da Silva

Email: ivanderson@gmail.com

Como citar: da Silva, I. P., de Lira, M. T. V., \& Voss, L. K. A. F. (2021). An intersectional analysis of the revolutionary limits and potentialities of youtube videos from the anti-racist perspective of Rita Von Hunt on the "Tempero Drag" channel. Revista Tempos e Espaços em Educação, 14(33), e17266. http://dx.doi.org/10.20952/revtee.v14i33.17266

\begin{abstract}
This study investigated the limits and revolutionary potential of YouTube Channels that, through informal education, constitute anti-capitalist niches. Its general objective was to analyze videos released on the channel "Tempero Drag" that focus on the issue of incarceration and genocide perpetrated by the hands of the Brazilian State against black and poor children, adolescents and young people. From a specific point of view, it aimed to investigate the limits that the YouTube platform presents for access to content that favors a rational analysis of material reality, based on the intersectional methodological approach, with a view to overcoming capitalism; explore the video channel "Tempero Drag" with a focus on contributions to an anti-racist and revolutionary training; and analyze the videos of this channel with a view to their potential for social agitation towards a society whose foundations are not grounded in racism. For this, the 232 videos of the Channel were verified and of these, two were selected: a) Racism, white thing; and b) War on Drugs. The treatment of the videos was based on the intersectionality of the struggles of social movements. As main results, we found that one of the biggest limiting factors of social transformation on the
\end{abstract}


left, through informal education, regimented on YouTube, within the limits of capitalism, even in niches of revolutionary power that have thousands of followers, are the people themselves. platform algorithms. Indeed, it is through the intersectionality of struggles that the revolution will be possible and not through the intersectionality of identities.

Keywords: Algorithms. Anti-capitalism. YouTube.

\section{RESUMO}

Esse estudo investigou os limites e potencialidades revolucionárias de Canais no YouTube que, pela via da educação informal, se constituem em nichos anticapitalistas. Teve por objetivo geral analisar vídeos divulgados no canal "Tempero Drag" que enfocam a questão do encarceramento e do genocídio perpetrado pelas mãos do Estado brasileiro contra crianças, adolescentes e jovens negras/os e pobres. Do ponto de vista específico, objetivou investigar os limites que a plataforma YouTube apresenta para o acesso aos conteúdos que favoreçam uma analítica racional da realidade material, baseado na abordagem metodológica interseccional, com vistas à superação do capitalismo; explorar o canal de vídeos "Tempero Drag" com foco nas contribuições para uma formação antirracista e revolucionária; e analisar os vídeos deste canal com vistas ao seu potencial de agitação social na direção de uma sociedade cujas bases não estejam alicerçadas no racismo. Para isso, foram verificados os 232 vídeos do Canal e desses, foram selecionados dois: a) Racismo, coisa de branco; e b) Guerra às Drogas. $O$ tratamento dos vídeos se baseou na interseccionalidade das lutas dos movimentos sociais. Como principais resultados constatamos que um dos maiores fatores limitadores de transformação social à esquerda, pela via da educação informal, arregimentada no YouTube, dentro dos limites do capitalismo, mesmo em nichos de potência revolucionária que contam com milhares de seguidores/as, são os próprios algoritmos da plataforma. Com efeito, é pela via da interseccionalidade das lutas que a revolução será possível e não pela via da interseccionalidade das identidades.

Palavras-chave: Algoritmos. Anticapitalismo. YouTube.

\section{RESUMEN}

Este estudio investigó los límites y el potencial revolucionario de los Canales de YouTube que, a través de la educación informal, constituyen nichos anticapitalistas. Su objetivo general fue analizar videos difundidos en el canal "Tempero Drag" que abordan la cuestión del encarcelamiento y el genocidio perpetrado por manos del Estado brasileño contra niños, adolescentes y jóvenes negros y pobres. Desde un punto de vista específico, tuvo como objetivo indagar los límites que presenta la plataforma YouTube para el acceso a contenidos que favorezcan un análisis racional de la realidad material, a partir del enfoque metodológico interseccional, con miras a la superación del capitalismo; explorar el canal de videos "Tempero Drag" con foco en aportes a una formación antirracista y revolucionaria; y analizar los videos de este canal con miras a su potencial de agitación social hacia una sociedad cuyos cimientos no estén cimentados en el racismo. Para ello se verificaron los 232 videos del Canal y de estos se seleccionaron dos: a) Racismo, cosa de blancos; yb) Guerra contra las Drogas. El tratamiento de los videos se basó en la interseccionalidad de las luchas de los movimientos sociales. Como principales resultados encontramos que uno de los mayores limitantes de la transformación social de la izquierda, a través de la educación informal, reglamentada en YouTube, dentro de los límites del capitalismo, incluso en nichos de poder revolucionario que cuentan con miles de seguidores, es el propio pueblo. Algoritmos de la plataforma. De hecho, es a través de la interseccionalidad de las luchas que la revolución será posible y no a través de la interseccionalidad de las identidades.

Palabras clave: Algoritmos. Aticapitalismo. Youtube. 


\section{INTRODUÇÃO}

A educação formal (aquela que se dá em creches, pré-escolas, escolas, universidades, etc.), bem como a educação não-formal (aquela que se dá em espaços como museus, centros de ciências, planetários, etc.), em todas as suas formas de expressão, estão orientadas para atender aos interesses do Estado. Tanto os processos de educação formal, quanto os de educação não-formal, se dão por meio de agentes, normas e instituições reguladas diretamente pelo Estado. Isto porque, segundo Almeida (2020, p. 92), para que a sociedade capitalista possa se sustentar, cabe ao Estado "a manutenção da ordem [...] e a 'internalização das múltiplas contradições', seja pela coação física [/execução], seja por meio da produção de discursos ideológicos justificadores da dominação". Desse modo, ao mesmo tempo em que o Estado assume um papel disciplinador interventivo constante - imprescindível ao modo de produção vigente -, por ter o capitalismo em suas bases, o Estado também é resultado dessas contradições.

Com efeito, essa relação dialética produz desequilíbrios sociais constantes que ora são mais facilmente contornáveis pelo aparato formal do Estado (judiciário), ora resultam em momentos de muita pressão os quais, segundo Mbembe (2018), exigem que se crie uma espécie de Estado de Sítio permanente no qual o aparato formal é posto de lado e entra em cena seu aparato repressivo com o grau de violência que a engrenagem capitalista exigir. Neste sentido, o que chamamos aqui de educação informal também não escapa a essa regra. Primeiro porque, ainda que informal, se dá em meio ao modo de produção capitalista; segundo porque, no campo da informalidade, múltiplas barreiras farão com que, caso seu potencial revolucionário apresente tendência à uma capilaridade universal, a própria necessidade do desenvolvimento capitalista, pela via do Estado, garantirá (pela ideologia ou pela repressão) que seu alcance seja tolhido até que essa ameaça tenha sido extinta.

Por outro lado, não se pode desconsiderar que existem investidas multilaterais, de potência revolucionária, que visam o desmonte do capitalismo e suas contradições. Dentre as potências revolucionárias, destacamos as relações sociais que contribuem para formar nossas subjetividades por meio das interfaces da internet, que, em nosso entendimento, se dão em máxima aproximação com o campo da educação informal. Segundo Bruno (2014) a educação informal se caracteriza por possuir um grau de liberdade e espontaneidade muito mais amplo que a educação formal e a educação não formal. Dentro dessa abordagem os conhecimentos "não são sistematizados, são transmitidos a partir da prática e da experiência anteriores, [...]. [e] não são esperados resultados $a$ priori, eles acontecem a partir do desenvolvimento do senso comum dos indivíduos que orienta as suas formas de pensar e de agir espontaneamente" (Bruno, 2014, p. 14). Partirmos da premissa de que, os Canais do YouTube, ao contornarem dentro dos limites do Capital, os liames do Estado, estão muito mais próximos, em potência, de se constituírem em espaços de educação informal.

Assim, nesta investigação enfocamos os aspectos gerais (limitadores e potencializadores) da interface YouTube, cujo proprietário é o gigante das tecnologias de software Google. Em meio aos nichos de potencial revolucionário ${ }^{1}$ que resistem no YouTube, destacamos, por seu alcance no Brasil, o canal "Tempero Drag", protagonizado por Rita von Hunt. A personagem - e o artista que a ela dá vida - se autodeclara uma "agitadora social comunista". Ela utiliza esse canal para criar uma alternativa de educação informal com vistas à elevação das consciências por meio de diálogos rigorosamente embasados em produções e evidências científicas. O contato com o público está alicerçado numa abordagem materialista e muito bem-humorada.

\footnotetext{
${ }^{1}$ Tratam-se se canais do YouTube que os/as autores desta pesquisa acompanham há pelo menos 03 anos e ao longo deste tempo têm demonstrado preocupação no sentido de arregimentar forças revolucionárias que vislumbram a superação do capitalismo. É o caso, por exemplo, dos canais: "TV Boitempo - com pouco mais de 300 mil inscritos/as https://www.youtube.com/c/TVBoitempo"; "Orientação marxista - com cerca de 37,5 mil inscritos/as https://www.youtube.com/channel/UCRLEkZpNRoZQBG8kUTBD8vQ"; "Tese onze - com cerca de 400 mil inscritos/as https://www.youtube.com/c/TeseOnze"; e "Tempero Drag - com cerca de um milhão de inscritos/as https://www.youtube.com/c/TemperoDrag". Esses números datam de 29/12/2021.
} 
Em meio aos variados temas abordados por Rita von Hunt, concentramos nossas atenções na análise do encarceramento e do genocídio perpetrados pelas polícias brasileiras contra crianças, adolescentes e jovens negras/os e pobres. Trata-se de um objeto cuja análise exige lentes interseccionais uma vez que um terço da população mais pobre do país é composta por pessoas pretas ou pardas (Borges, 2020). Além disso, o Anuário Brasileiro de Segurança Pública de 2021, apontou que, 722.353 pessoas do sexo masculino $(95,1 \%)$ e 37.165 do sexo feminino $(4,9 \%)$, estavam privadas de liberdade no ano de 2020. Desses/as, 48,6\% tinham entre 18 e 29 anos de idade; $66,3 \%$ são/eram negros/as²; e quase $80 \%$ cumprem/cumpriam pena em regime fechado ou são/eram presos/as provisórios/as.

Esse relatório nos informa ainda que, também são os/as negros/as os/as mais vulneráveis a mortes violentas intencionais (Anuário Brasileiro de Segurança Pública, 2021). Com efeito, de cada 100 sujeitos/as "entre 15 e 19 anos que morreram no país por qualquer causa, 39 foram vítimas da violência letal" (Cerqueira et al., 2021, p. 27). Em meio a população jovem brasileira, o Atlas da Violência de 2021 nos informa que "entre aqueles que possuíam de 20 a 24 [anos de idade], foram 38 vítimas de homicídios a cada 100 óbitos e, entre aqueles de 25 a 29 anos, foram 31" (Cerqueira et al., 2021, p. 27). Assim, "dos 45.503 homicídios ocorridos no Brasil em 2019, 51,3\% vitimaram jovens entre 15 e 29 anos. São 23.327 jovens que tiveram suas vidas ceifadas prematuramente, em uma média de 64 jovens assassinados[/as] por dia no país" (Cerqueira et al., 2021, p. 27).

Neste sentido, se "a pobreza no Brasil tem cor" (Borges, 2020, p. 113) e neste país "classe e raça são elementos socialmente sobredeterminados" (Almeida, 2020, p. 185), então, diante dos dados apontados pelo Anuário Brasileiro de Segurança Pública de 2021 e pelo Atlas da Violência de 2021, podemos afirmar que os alvos do encarceramento e/ou das mortes violentas intencionais são o povo negro e pobre, dentre os quais crianças e adolescentes, mas principalmente aqueles a partir dos 13 anos.

Esses dados, por sua urgência de reversão, justificam nossa escolha pelo tema a ser analisado em meio às videoaulas do Canal do YouTube "Tempero Drag". Contudo, se Engels e Marx (2007, p. 47) acertaram ao afirmar que, "as ideias da classe dominante são, em cada época, as ideias dominantes", obviamente o próprio meio no qual o Canal está inserido se encarregará de erguer as barreiras necessárias para que vozes como as de Rita von Hunt, que denunciam e lutam pela reversão dos dados supracitados, se dissipem nas tramas dos algoritmos da Internet. Essa hipótese é apresentada aqui porque, não cremos que seja de interesse do YouTube que conteúdos potencialmente revolucionários contrários ao capitalismo ganhem capilaridade mundial. Assim, é provável que, ao se apresentar como uma via de educação informal com foco anticapitalista, o material veiculado em Canais do YouTube como o "Tempero Drag", tenham suas chances de capilaridade global muito próximas a zero em função da própria lógica empresarial do YouTube e pela forma como operam os seus algoritmos.

A título de exemplo é possível mencionar que, segundo a empresa multimídia dedicada a apoiar vozes independentes em jornalismo investigativo, cinema, arte, cultura, mídia e entretenimento -"The Intercept - Brasil", cinco entre os 10 canais que mais cresceram em termos de visualizações no ano de 2018 (ano das eleições presidenciais no Brasil) se dedicava a promover conteúdos conservadores e de Extrema Direita. Para isso, segundo o "The Intercept - Brasil" foi necessária "uma mãozinha [sic.] do algoritmo do YouTube que recomenda conteúdo na seção 'Em Alta', área nobre do site que mostra os canais e vídeos que estão 'bombando' [sic.] no momento" (The Intercept Brasil, 2019, online). Essa organização em parceria com a organização "Manual do usuário" 3 "se debruçaram sobre mais de 17 mil rankings 'Em Alta' do YouTube no Brasil veiculados durante o segundo semestre de 2018, coletados e organizados pela empresa de análise de dados

\footnotetext{
${ }^{2}$ Apenas $79 \%$ daqueles/as que estão privados/as de liberdade tiveram sua cor/raça informada

${ }^{3}$ Disponível em: https://manualdousuario.net/sobre/
} 
'Novelo'”4 (The Intercept Brasil, 2019, online). O resultado dessas análises foi a descoberta de que, "canais até então irrelevantes - que nunca tinham aparecido no ranking - explodiram no período eleitoral, recomendados milhares e milhares de vezes pelo algoritmo do YouTube" (The Intercept Brasil, 2019, online).

Neste sentido, evidencia-se que "o próprio algoritmo da plataforma não é neutro na exibição do conteúdo. Porquanto, prioriza aquilo de mais rentável para a plataforma, em detrimento do conteúdo não impulsionado" (Ende \& Oliveira, 2020, p. 22-23). Sobre esse aspecto, organizações jornalísticas sérias como a "Revista Carta Capital" e o site "UOL", divulgaram que, 12 canais do YouTube, de tônica conservadora e de extrema direita, simpáticos ao presidente eleito em 2018, chegaram a receber, pelo menos, 5,6 milhões de reais em monetização do YouTube pelo número de acessos e compartilhamentos que receberam num período de dois anos (2018-2020) (Carta Capital, 2021; UOL, 2021). Assim, a lógica por meio da qual opera o YouTube, do ponto de vista material, se constitui enquanto barreira para que o potencial revolucionário de Canais como o "Tempero Drag" se converta em ato revolucionário. Com efeito, o que se tem percebido diante do material que é disposto neste Canal são alternativas de educação informal, elementos que contribuem para uma reflexão sobre as alternativas de superação da sociedade capitalista em prol de um modo mais humano e mais igualitário de sociabilidade.

Para a manutenção do estado de coisas, ou seu aprofundamento, observa-se ainda outra barreira: a simbiose entre a estrutura do modo de produção capitalista e a forma como o capitalismo se reproduz no cenário atual, mantém uma íntima relação com as estruturas psíquicas dos seres humanos. Tal fenômeno se manifesta "não somente no sentido de que a ideologia dominante é a ideologia da classe dominante, mas também [...] no sentido de que as contradições da estrutura econômica da sociedade estão enraizadas na estrutura psicológica das massas oprimidas" (Reich, 2001, p. 22). Isso faz com que os interesses dos membros da classe trabalhadora e que navegam no YouTube convirjam mais fortemente para conteúdos que apontem na direção do aprofundamento do modo de produção vigente, ou seja à ideologia da classe dominante. Assim, na medida em que os algoritmos do YouTube trabalham a favor do capitalismo e de sua reprodução, o Estado, como mantenedor do capitalismo, por meio de suas instituições, opera para que os interesses da classe trabalhadora, paradoxalmente, estejam ombro a ombro com os interesses do Capital.

Ao se insurgir no interior do YouTube como uma força contrária à sociedade capitalista, o canal "Tempero Drag" assume uma intenção pedagógica subversiva à lógica do próprio YouTube, uma vez que esse está claramente a serviço do Capital e de sua reprodução. Nesse sentido, ao mesmo tempo em que os/as usuários/as do YouTube buscam, majoritariamente, conteúdos consoantes aos interesses do Capital, os algoritmos do YouTube também polarizam os resultados das buscas em favor da reprodução do modo de produção vigente. Se não fosse assim, o YouTube seria o oposto do que ele é. A partir do momento em que ele se voltar contra seus próprios interesses mercantis e se constituir como uma ameaça real ao sistema capitalista, o próprio Google dará conta de encerrá-lo. Essa manobra seria necessária porque, no atual modo de produção, "os indivíduos precisam ser formados, subjetivamente constituídos, para reproduzir em seus atos concretos as relações sociais, cuja forma básica é a troca mercantil. Nisso, resulta o fato de que um indivíduo precisa tornar-se um trabalhador ou um capitalista" (Almeida, 2020, p. 168). Como as chances de um/a membro da classe trabalhadora se tornar um capitalista também são muito próximas a zero, deixando claro que isso não se opõe a lógica do capital e que pode estar em perfeita sintonia com ela, é imprescindível que se garanta a forja de consciências racistas no interior do capitalismo. "Não é por outro motivo que parte da sociedade entende como um mero aspecto cultural o fato de negros e mulheres receberem os piores salários e trabalharem mais horas, mesmo que isso contrarie disposições legais" (Almeida, 2020, p. 169).

\footnotetext{
${ }^{4}$ Disponível em: https://www.novelo.io/
} 
Assim, o racismo se manifesta tanto do ponto de vista objetivo, quanto do ponto de vista subjetivo. Com efeito, o conteúdo e a forma como Rita von Hunt aborda as contradições sociais e, em especial a questão do encarceramento e do genocídio brasileiro perpetrado pelas polícias brasileiras contra crianças, adolescentes e jovens negras/os e pobres, foi tomado como objeto dessas análises, pois podem contribuir para a luta contra o capitalismo e para a construção de uma sociedade igualitária. Desse modo, a partir da exploração dos vídeos dispostos por Rita von Hunt, emergiu a seguinte pergunta de pesquisa: Quais os limites e potencialidades revolucionárias de Canais no YouTube que, pela via da educação informal, se constituem em nichos de agitação anticapitalista?

Isto posto, delineamos como objetivo geral deste estudo: analisar vídeos produzidos e divulgados no canal "Tempero Drag" que enfocam a questão do encarceramento e do genocídio perpetrado pelas mãos do Estado brasileiro contra crianças, adolescentes e jovens negras/os e pobres, baseado numa abordagem metodológica interseccional. A partir desse recorte, delineamos os seguintes objetivos específicos: investigar os limites que a plataforma YouTube apresenta para o acesso aos conteúdos que favoreçam uma analítica racional da realidade material com vistas à superação do capitalismo; explorar o canal de vídeos "Tempero Drag" com foco nas contribuições para uma formação antirracista e revolucionária; e analisar os vídeos deste canal com vistas ao seu potencial de agitação social na direção de uma sociedade cujas bases não estejam alicerçadas no racismo.

Apresentamos nas seções subsequentes os resultados dos movimentos de pesquisa que alçamos. Num primeiro momento discutimos acerca da relação entre a lógica com que operam os algoritmos do YouTube e sua tendência a conteúdos extremistas de direita, (ultra)conservador(es) e de viés ideológico em favor da manutenção do capitalismo; na sequência apresentamos a descrição panorâmica do Canal do YouTube "Tempero Drag" protagonizado por Rita Von Hunt; em continuidade, tecemos uma análise da abordagem da questão das execuções de crianças, adolescentes e jovens negros/as e pobres perpetradas pelo Estado através de suas polícias tomando por base a argumentação construída nos vídeos divulgados no canal em tela.

\section{A QUEM ATENDEM OS ALGORITMOS DO YOUTUBE?}

Por vezes, a internet pode se constituir como um lócus de potencialidades formativas, por vezes pode se constituir num grande conglomerado de desinformação e que contribui para que os/as sujeitos/as diminuam sua capacidade de racionalidade acerca da realidade material mais imediata (Sued, 2020). Não à toa, duas indústrias chamam seus clientes de "usuários". A indústria das drogas ilícitas e a indústria das grandes potências da internet. Não é à toa também que, partilhando da mesma lógica da expectativa de que os/as "usuários/as" se tornem seus dependentes, não é incomum que o vício nos faça navegarmos, horas e horas, em meio ao imenso oceano de informações disponíveis nas interfaces da internet. A letargia diante da tela do smartphone é cada vez mais comum entre as pessoas que já foram abatidas pela desesperança em dias melhores no campo da realidade material. Para essas pessoas, o virtual das interfaces da internet dá algum sentido à sua existência.

Tanto potencial humano é diariamente perdido para a indústria das comodities da internet (Google, Facebook e Instagram) que estão intimamente alinhadas à necessidade de que as pessoas se distanciem cada vez mais da realidade material e não produzam um levante contra aquilo que as oprime. As interfaces desses gigantes do mercado de tecnologia de software não são neutras. Elas possuem a capacidade de captar e acumular dados sobre seus/suas usuários/as e utilizá-los em prol de seus objetivos de lucro. Dificilmente uma pessoa, ao ser perguntada se é capaz de expressar 500 dados sobre si mesma conseguirá fazê-lo de pronto. Enquanto isso, o Facebook, segundo informações de um ex-funcionário, divulgadas no Documentário "O Dilema das Redes" (O Dilema das Redes, 2020), possui pelo menos 50.000 dados de cada usuário/a. 
Ao conhecer o perfil de cada pessoa, as vezes melhor que ela mesma, os algoritmos das interfaces da internet conseguem identificar as fragilidades do/a usuário/a e, fazendo-o/a pensar que está escolhendo o que consumir diante da tela do computador, ou do smartphone, o/a conduz aos resultados que são de interesse da interface digital na qual está navegando. Nesse sentido, não é incomum que, mesmo um/uma usuário/a com inclinação política à esquerda, ao digitar o termo "Política" no YouTube, obtenha como resultado da busca uma lista infindável de resultados cuja maioria absoluta é de inclinação à direita ou de extrema direita. Isso não quer dizer que o algoritmo de busca do YouTube, detendo o volume de informações sobre esse/a usuário/a não "saiba" que seu interesse sobre política não é de conteúdos patronais, privatistas, xenofóbicos, racistas ou sexistas. Isso quer dizer que o algoritmo do YouTube "sabe" dos riscos à manutenção do sistema capitalista caso as pessoas minimamente interessadas em "Política" possam acessar com facilidade o grande volume de material de qualidade disponível em seu repositório com viés ideológico à esquerda.

Assim, os resultados de busca são propositais e frutos de estratégias muito bem pensadas para prender a atenção do/da usuário/a pelo maior tempo possível diante de "conteúdos vazios" ou de viés ideológico conservador e de extrema direita. Tanto mais o/a usuário/a clique, curta, acesse uma página, forneça dados, quaisquer dados, mais informações lhes serão ofertadas, informações personalizadas para que sua experiência com as interfaces da internet seja cada vez mais duradoura, alienante da realidade material e empobrecedora de sua subjetividade. Tanto mais tempo se passe na frente do computador, mais tempo se estará exposto/a às múltiplas formas de anúncios e propagandas dos/as empresários/as que, ao deter mais dados sobre o/a usuário/a, pela via do controle ideológico, "quase" que o/a forçará a comprar cada vez mais, ainda que a mercadoria a ser consumida não tenha utilidade material para os/as sujeitos/as.

Reis, Zanetti e Frizzera (2018, p 38) afirmam que, "em apenas três anos, o consumo de vídeos na web cresceu 90,1\%" e nesse período (2006-2008)", o YouTube "deixa de ser apenas um repositório de vídeos caseiros e clipes musicais para ser 'colonizado' por vloggers, youtubers e diversos tipos de produtores de conteúdo" (Reis, Zanetti \& Frizzera, 2018, p 38, grifos dos/as autores/as). Sobre essa questão, o estudo de Ende e Oliveira (2020, p. 22), nos alerta que "o[/a] usuário[/a] médio[/a] sabe muito pouco sobre a existência e a abrangência da delimitação que é feita para si, e menos ainda sobre os motivos por que isso ocorreu, mantendo uma crença geral na imparcialidade e neutralidade das plataformas". Os algoritmos, portanto, "medeiam a experiência entre o usuário e o ciberespaço ${ }^{5}$, oferecendo-o[/a] certos conteúdos em detrimento de outros" (Ende \& Oliveira, 2020, p. 20).

Para compreendermos melhor esses processos, é necessário compreendermos em que consiste um algoritmo. Segundo Ende e Oliveira (2020, p. 21), nesse contexto, "algoritmos são sequências de passos escritos em código de computador com um objetivo específico a ser alcançado a partir de sua execução". Assim, em função do volume de dados que circulam na rede mundial de computadores, sem a presença dos algoritmos, a experiência do/a usuário/a comum com a internet seria impossível. "A miríade de dados que circula na rede torna impossível uma interpretação e valoração humana efetiva do conteúdo, de modo que a desorganização a tornaria obsoleta [...] os algoritmos indicam o assunto de mais relevância conforme uma busca feita pelo[/a] usuário[/a] ou direcionam as postagens para cada indivíduo conforme suas preferências" (Ende \& Oliveira, 2020, p. 21). Contudo, como tais interfaces não são neutras, os resultados de busca não refletem necessariamente as preferências dos/as usuários/as, mas uma tendência às preferências da própria interface digital que está sendo explorada.

\footnotetext{
${ }^{5} \mathrm{O}$ ciberespaço pode ser compreendido como o resultado das interações entre os/as/es usuários/as/es das interfaces da internet. Ele difere da Internet porque a Internet é a conexão física entre computadores. O ciberespaço é o produto das interconexões entre os/as/es usuários/as/es que exploram a Internet por meio de suas interfaces.
} 
No campo do desenvolvimento dessas interfaces digitais, a sofisticação dos algoritmos faz com que o/a usuário/a tenha a impressão de que a escolha é dele/a. Na verdade, não é! Ao tratarmos especificamente dos algoritmos do YouTube é necessário compreender que, segundo Sued (2020), o YouTube reflete uma média de dois bilhões de visitas por mês e ocupa o segundo lugar no mundo entre as plataformas mais visitadas. Além disso, Reis, Zanetti e Frizzera (2018, p 36) afirmam que o YouTube é "a maior plataforma de circulação e consumo de vídeos on-line no Brasil". Esses/as autores/as explicam que essa plataforma "funciona mediante busca por palavra-chave, que é respondida com uma lista de vídeos considerados mais relevantes. A cada vídeo selecionado pelo/a usuário/a, uma outra lista de vídeos é apresentada do lado direito da tela, compondo assim um conjunto de recomendações da plataforma. [...]" (Reis, Zanetti \& Frizzera, 2018, p 36).

Os metadados (dados sobre dados) possibilitam ao algoritmo localizar e sugerir aos/às usuários/as vídeos específicos "dentro da base de arquivos em vídeos enviados ao YouTube" (SILVA, 2012, p. 14). Com efeito, desde o acesso à plataforma, passando pela busca do/a usuário/a, chegando na listagem de vídeos, sendo atravessados/as pelas propagandas pagas e vídeos patrocinados que se entremeiam na tela do computador (ou do smartphone), "Ia enorme cantidad de información publicada se organiza según la lógica de algoritmos de recomendación que priorizan y filtran contenidos modelando los consumos de información de los usuários [... $]^{6 \prime \prime}$ (Sued, 2020, p. 167). Neste sentido, se por um lado os algoritmos são fundamentais para que os dados contidos na internet possam ser lidos pelos/as usuários/as; por outro, podem causar um estreitamento na percepção que os sujeitos captam da realidade material. Com efeito, tais algoritmos não são divulgados com precisão pelo YouTube, tampouco são divulgados os dados de seus/suas usuários/as, que a plataforma possui.

O que se sabe é que, dentre os algoritmos mais comuns é possível destacar aqueles que são responsáveis pela "formação de perfis. Estes recebem dados sobre o comportamento da pessoa a partir de seus rastros deixados na internet, como publicações, frequências de visitas em websites, localizações coletadas e [a partir desses dados] identificam características sobre as tendências de ações e gostos de cada pessoa" (Ende \& Oliveira, 2020, p. 21). Tais dispositivos lógicos "atuam de maneira a prever os possíveis novos interesses e direcionar anúncios específicos para cada um/uma, maximizando lucros dos anunciantes que têm sua propaganda veiculada às pessoas mais propensas a comprar seu produto [...]" (Ende \& Oliveira, 2020, p. 21). Essas "formas de seleção de conteúdo convergem na medida em que são postas em prática com a finalidade de manter o/a usuário/a conectado/a à plataforma por mais tempo, aumentando, assim, sua exposição às propagandas veiculadas ali e elevando os lucros da empresa" (Ende \& Oliveira, 2020, p. 21).

Esse princípio lógico, apesar de ser de baixa complexidade, não é, nem de longe, o único utilizado pelo YouTube. Na medida em que se aperfeiçoa, segundo Reis, Zanetti e Frizzera (2018, p 44), 0

YouTube passou a usar machine learning para produzir recomendações ranqueadas para os usuários. [...] O sistema é composto por duas redes neurais profundas (deep neural networks): uma para seleção e filtragem, e outra para ranqueamento de vídeos relevantes. Na fase de seleção, o algoritmo leva em consideração o histórico de atividades do usuário (vídeos assistidos, interações, assinaturas de canais, comentários, buscas anteriores e demografia) como variáveis para produzir uma amostra de possibilidades dentro da coleção de vídeos do YouTube. Essa seleção corresponde a uma lista de vídeos relevantes para o usuário, mas sem ordem de importância definida. A segunda etapa se concentra em hierarquizar essa seleção para criar uma lista de recomendações otimizada para cada usuário. O algoritmo designa uma pontuação (score) para cada vídeo usando uma série de recursos que descrevem tanto as

\footnotetext{
${ }^{6}$ Tradução livre: "A enorme quantidade de informação publicada é organizada de acordo com a lógica de algoritmos de recomendação que priorizam e filtram conteúdos, modelando o consumo de informação dos usuários [...]" (Sued, 2020, p. 167).
} 
atividades do perfil, quanto atributos do vídeo (título, canal, número de visualizações, likes e dislikes, comentários, recomendações anteriores, data de publicação etc.). A lista completa desses atributos e o peso relativo de cada uma delas não são revelados pelo YouTube. No final do processo, os vídeos de maior pontuação são apresentados ao usuário numa lista ordenada ao lado ou abaixo do vídeo que o[/a] usuário[/a] está assistindo. Importante ressaltar que esses processos são atualizados continuamente pelos desenvolvedores do YouTube. $\mathbf{O}$ ranking pode ser manipulado por processos internos ou externos. Por exemplo, à lista podem ser adicionados vídeos patrocinados, anúncios ou vídeos não relacionados para fins de testes. Da mesma maneira, vídeos podem ser excluídos da lista por infringir copyright, conter material impróprio ou por decisões judiciais. (grifos nossos).

Nesse nível de controle e com o grau de capilaridade social do YouTube, essa plataforma se constitui como uma interface digital com "o poder de moldar a visão de mundo e a percepção da verdade que muitos[/as] recebem pela rede. Assim, ao representar pessoas negras como macacos, [...] e exibir páginas preponderantemente pornográficas para a busca por 'meninas negras', a plataforma e seus algoritmos estimulam a percepção popular” (Ende \& Oliveira, 2020, p. 23-24). Neste caso, reforçam, muitas vezes de maneira sutil, o preconceito racial contra o povo negro. Essas exposições ocorrem corriqueiramente, sem causar grandes estranhamentos, porque a sociedade capitalista está estruturada sobre os pilares do racismo (Almeida, 2020).

O racismo, não pode ser confundido, por exemplo, com preconceito de raça ou discriminação de pessoas racializadas. Essas ações são perpetradas individualmente ou em pequenos grupos e remetem a desvios morais comportamentais, o que é um engodo já que o racismo não está localmente situado dentro de um/a ou outro/a sujeito/a. O racismo é um sistema de opressão, historicamente construído, baseado na fragmentação do gênero humano em grupos superiores e inferiores e que utiliza para isso, o subterfúgio das diferenças de traços fenotípicos entre sujeitos/as não-racializados/as e racializados/as.

As formas como o racismo se reproduz na sociedade capitalista acompanham a evolução deste modo de produção e portanto, estão em constante reformulação. Nesse sentido, é imprescindível que o campo da Educação esteja atento ao potencial (desin)formativo do YouTube e vigilante aos princípios de funcionamento de seus algoritmos. Percebe-se que esses algoritmos polarizam a percepção da realidade material. Estamos tratando de uma plataforma virtual que está (desin)formando muito mais sobre esses temas do que os espaços formais e não-formais de ensino. Isso pode ser facilmente comprovado pelos números de visualizações dos vídeos que lá estão. Nesse sentido, Sued (2020) nos alerta para o perigo de uma "infodemia", que pode ser definida como uma "rápida diseminación de información falsa en plataformas sociales y diversos medios de comunicación"7 (Sued, 2020, p. 24). Esses processos só são possíveis porque os algoritmos são determinantes para a propagação de conteúdos (des)informativos, mas também sinalizam para uma "dificuldade" de controle na propagação de conteúdos falsos.

O caminho que se percorre dentro do YouTube, de um primeiro para um segundo vídeo, e depois para um terceiro recomendado pela plataforma, ad infinitum, polariza a experiência dos/as sujeitos/as com essa interface para que esses/as entrem numa "cámara de eco desinformativa" (Sued, 2020, p. 177). Ende e Oliveira (2020) acrescentam que o algoritmo tende a suscitar "emoções negativas, como o medo e o ódio" (Ende \& Oliveira, 2020, p. 22) e são justamente essas emoções que têm feito com que números tão baixos de visualizações sejam atribuídas à discussões cognitivamente mais densas e números astronômicos sejam atingidos por vídeos de conteúdo de orientação ideológica (ultra)conservadora e de extrema direita.

\footnotetext{
7 Tradução livre: "Divulgação rápida de informações falsas em plataformas sociais e diversos meios de comunicação" (Sued, 2020, p. 24).
} 
Dessas argumentações, fica claro que as limitações/barreiras impostas ao potencial pedagógico revolucionário dos Canais do YouTube, não são ontológicas à interface digital. $\mathrm{O}$ real problema é anterior; diz respeito à lógica de mercado sob a qual ele está submetido. Vale a pena sempre recordar que os algoritmos operam com muitos dados sobre aqueles/as que navegam na internet e "que certas postagens serão mostradas a mais pessoas ou a pessoas específicas, com vantagem sobre outras. Assim, não basta apenas publicar o conteúdo na rede para ser ouvido[/a]: pode-se ser silenciado simplesmente pela prevalência de outro discurso por impulsionamentos financeiros" (Ende \& Oliveira, 2020, p. 22). Nessa perspectiva, longe de ser neutro, o YouTube, assim como todas as interfaces da internet, é mediado pelos algoritmos que apreendem, modulam e moldam as preferências dos/as usuários/as.

Assim, é preciso construir novas formas de resistência ao entretenimento vazio ou à informação vazia que está disponível em monta, numa das interfaces da Internet mais acessadas do mundo. É preciso subverter a lógica dessa potente interface digital, mesmo diante de suas limitações para a construção de um front revolucionário. Neste sentido, Rita von Hunt, têm resistido neste front encabeçando a luta anticapitalista, dentro do YouTube, por meio do canal "Tempero Drag". Acerca das características deste canal, discutiremos a seguir.

\section{O CANAL DO YOUTUBE “TEMPERO DRAG”, POR RITA VON HUNT}

O "Tempero Drag" é um canal do YouTube, que trata de problemáticas sociais de forma séria, mas sempre que possível bem-humorada, de educação informal, que visa uma formação crítica e é protagonizado por uma Drag Queen: Rita von Hunt. O ator que se "monta" e que dá vida à personagem é professor de Literatura formado pela Universidade de São Paulo (USP). Rita von Hunt também é professora de Literatura, mas em seus vídeos se ampara também em leituras clássicas, modernas e contemporâneas do campo da Sociologia, da Economia, da Filosofia, da Educação, da História e da Analítica Social em geral. Os vídeos do "Tempero Drag", assumem as características de verdadeiras videoaulas. Em seus vídeos Rita von Hunt demonstra que uma Drag Queen, pode ser também uma divulgadora científica, uma agitadora social, uma professora de Literatura, uma intelectual.

O canal contava, em janeiro de 2022, com mais de 965 mil inscritos e assumia o compromisso de lançar um vídeo novo todas as quintas-feiras de cada semana. Alguns vídeos foram muito mais visualizados que outros. $O$ desenho metodológico deste estudo foi constituído a partir da navegação pelos vídeos listados no canal "Tempero Drag" na perspectiva do/a usuário/a. A esse procedimento denominamos método de superfície (Sued, 2020). A análise de superfície foi realizada a partir de três computadores geograficamente distantes, por três analistas distintos/as. Até o momento do fechamento deste artigo, o canal "Tempero Drag" possuía 236 vídeos publicados. 0 material com maior número de visualizações, até o momento supracitado, foi o vídeo intitulado "BÍBLIA: A ESCRITURA SAGRADA????????". Esse vídeo havia sido publicado em 21 de maio de 2019 e até o dia 31 de janeiro de 2022 havia atingido 1.406 .107 visualizações.

Com efeito, o canal em tela teve seu primeiro vídeo publicado em 26 de abril de 2015 com título "Temperamental" (esse vídeo até o dia 31 de janeiro de 2022 contava com 39.168 visualizações). Trata-se de um vídeo curto de 37 segundos que se presta a servir como abertura do canal. O "Tempero Drag", em sua origem, era dedicado a uma abordagem humorística de receitas de comidas veganas e temas de interesse da comunidade Drag. É somente a partir do primeiro semestre de 2018 que o canal muda a sua tônica e passa a tratar, cada vez com maior rigor científico e cada vez com maior intensidade, de temas sociais articulados com análises interseccionais, sobremaneira a partir do viés teórico do marxismo.

Em face do recorte necessário às análises pretendidas dentro do escopo de um artigo, selecionamos dentre os 236 vídeos do canal, 02 deles que enfocam mais especificamente a problemática das mortes de crianças, adolescentes e jovens negras/os e pobres pela mão do Estado. 
São eles: a) Racismo, coisa de Branco, e b) Guerra às drogas. A descrição desses vídeos pode ser verificada na tabela 1.

Tabela 1. Corpus da Pesquisa.

\begin{tabular}{|c|c|c|}
\hline Título & Dados do Vídeo & Sinopse \\
\hline $\begin{array}{l}\text { Racismo, coisa } \\
\text { de Branco }\end{array}$ & $\begin{array}{l}\text { O vídeo possui } 26^{\prime} 16^{\prime \prime} \text { de duração e } \\
\text { foi publicado em 19/06/2020. Até o } \\
\text { momento desta pesquisa possuía } \\
765.826 \text { mil visualizações. Está } \\
\text { Disponível em: } \\
\text { https://www.youtube.com/watch?v= } \\
\text { eBfw2WqNDj0 }\end{array}$ & $\begin{array}{l}\text { O vídeo resulta de um esforço de análise interseccional } \\
\text { de gênero, raça e classe uma vez que evidencia, por } \\
\text { exemplo, uma maior probabilidade de miséria e morte } \\
\text { para mulheres transsexuais/travestis negras e faveladas } \\
\text { do que para homens brancos cisgêneros pertencentes } \\
\text { às classes mais abastadas da sociedade. O argumento } \\
\text { central é o de que, para construção de uma sociedade } \\
\text { igualitária é necessária a conscientização do povo } \\
\text { racializado acerca de suas potências e limitações numa } \\
\text { sociedade racista, bem como a conscientização do povo } \\
\text { não-racializado de que, por mais bem intencionados que } \\
\text { sejam, se beneficiam da estrutura racista desta } \\
\text { sociedade. }\end{array}$ \\
\hline Guerra às drogas & $\begin{array}{l}\text { O vídeo possui } 17^{\prime} 08^{\prime \prime} \text { de duração e } \\
\text { foi publicado em } 17 / 12 / 2019 \text {. Até o } \\
\text { momento desta pesquisa, o vídeo } \\
\text { possuía } 560.860 \text { visualizações. } \\
\text { Está disponível em: } \\
\text { https://www.youtube.com/watch?v=- } \\
\text { JS27esNdkE }\end{array}$ & $\begin{array}{l}\text { O vídeo enfoca as implicações da Política de Estado } \\
\text { travada sob o slogan de "Guerra às Drogas" em nome da } \\
\text { qual várias crianças, exclusivamente as residentes em } \\
\text { comunidades periféricas ou faveladas, têm sido } \\
\text { assassinadas pelas balas das polícias brasileiras. A } \\
\text { preocupação central do vídeo é conscientizar a } \\
\text { população de que, na Guerra às Drogas, as balas } \\
\text { perdidas das polícias, sempre encontram um corpo } \\
\text { negro infantil, jovem ou adulto para alvejar. A ênfase no } \\
\text { corpo negro se dá porque a "Guerra às Drogas" na } \\
\text { realidade só atinge o povo pobre e esse, é, em sua } \\
\text { quase totalidade, negro. }\end{array}$ \\
\hline
\end{tabular}

Ao selecionar esse material, captamos o áudio do vídeo por meio da plataforma y2mate.com (https://www.y2mate.com/pt70). Em seguida, de posse do áudio do vídeo em formato MP3 (MP3 50k), utilizamos o Software Audacitty (https://www.audacityteam.org/) para fragmentar os áudios dos vídeos em faixas de $1 \mathrm{~min}$, ou menos. Esse procedimento foi necessário tendo em vista que utilizamos o software Transcrible by Wreally (https://transcribe.wreally.com/transcriptions), em sua versão paga. Utilizamos esse software porque ele garante uma taxa média de $90 \%$ de acerto na transcrição. O elemento de maior limitação neste software é que ele só permite a transcrição de um minuto de áudio por vez. Mesmo com a transcrição via software, as opções metodológicas exigiram rigorosa revisão artesanal, além da fragmentação dos áudios captados dos vídeos.

Para a análise dos dados coletados, recorremos à perspectiva teórico-metodológica da interseccionalidade. Para Kimberlé Crenshaw (2002, p. 175), precursora do conceito, a interseccionalidade diz respeito à "conceitualização do problema que busca capturar as consequências estruturais e dinâmicas da interação entre dois ou mais eixos da subordinação". Contudo, como nos alertou Ochy Curriel, os fundamentos do pensamento de Crenshaw acerca da interseccionalidade, enquanto método analítico, se constitui numa proposta liberal, por meio da qual, primeiro se assume que as identidades se constroem de maneira autônoma, para depois produzir - como o próprio nome sugere - o cruzamento dessas análises identitárias (Teixeira, Silva \& Figueiredo, 2017).

No entanto, embora a preocupação de Ochy Curriel com "o problema da interseccionalidade" seja legítimo e não possa ser desconsiderado, é imprescindível registrar que a filósofa norte-Americana comunista Ângela Davis, em seu clássico "Mulheres, Raça e Classe" (Davis, 2016) teceu uma análise interseccional rigorosa das condições das mulheres negras, desde o 
período escravista até a contemporaneidade, nos Estados Unidos, sob as lentes anticapitalistas do marxismo. Assim, ainda que suas origens remontem aos ideais do liberalismo econômico, sob o prisma da análise fragmentada das identidades e seus intercruzamentos, Davis (2016) desenvolveu um método de análise interseccional que não se reduz ao entrecruzamento de análises.

Dentro desta perspectiva a interseccionalidade "visa dar instrumentalidade teóricometodológica à inseparabilidade estrutural do racismo, capitalismo e cisheteropatriarcado" (Akotirene, 2020, p. 19). Neste sentido, Davis (2018) conclama os movimentos sociais a abandonarem a interseccionalidade das identidades em favor da interseccionalidade das lutas em favor de um movimento revolucionário e unificado. Em consonância com o método proposto por Davis $(2016,2018)$, dispomos a seguir as análises da abordagem de Rita von Hunt acerca da questão do encarceramento e do assassinato de crianças, adolescentes e jovens negras/os e pobres pela mão do Estado.

\section{EDUCAÇÃO INFORMAL E NECROPOLÍTICA}

Ao constatarmos que os povos negros são um dos povos mais vulneráveis às mortes violentas intencionais, que de cada 100 sujeitos/as entre 15 e 19 anos que morreram no país, por qualquer causa, 39 foram vítimas da violência letal; que $51,3 \%$ de todos os homicídios registrados em 2019, vitimaram jovens entre 15 e 29 anos; que aqueles que possuíam de 20 a 24 anos, foram 38 vítimas de homicídios a cada 100 óbitos e, que entre aqueles de 25 a 29 anos, foram 31; que o Brasil registra uma média de 64 jovens assassinados[/as] por dia no país, percebemos que não estamos diante do poder de prolongar a vida ou deixar morrer, mas do poder de colocar o povo negro, sob a ameaça constante da morte, desde as mais tenras idades. Com efeito, uma significativa parcela dessas mortes de jovens negros é perpetrada pela mão armada do Estado cujos alvos começam quando um/a negro/a completa 13 anos de idade (Anuário Brasileiro de Segurança Pública, 2021; Cerqueira et al., 2021).

Esse cenário diz respeito à uma necropolítica. Ou seja, uma ação colonialista ${ }^{8}$ que, no caso brasileiro, tem como alvos principais os remanescentes dos povos originários e os remanescentes dos povos traficados do continente africano para essas terras a partir de 1549. Segundo Almeida (2020, p. 117), "o colonialismo não mais tem como base a decisão sobre a vida e a morte, mas tão somente o exercício da morte, sobre as formas de ceifar a vida ou de colocá-la em permanente contato com a morte". Para isso, é imprescindível que se crie um pânico social que legitime, pela via do apoio popular, um Estado de exceção, aquele no qual não há democracia e os direitos civis ficam suspensos; ou um Estado de sítio, aquele no qual a ação do Estado ganha novos contornos jurídicos em função de uma guerra ou uma situação extrema de calamidade pública.

Trata-se de um Estado que não tem mais paciência para "deixar morrer". A necropolítica consiste no poder do Estado em, sob o abrigo do medo e do ódio, instaurar um pânico social no qual as pessoas se convencem de que são inimigas umas das outras e que as existências de determinados grupos se constituem como ameaças às suas próprias vidas. O caldo resultante da mistura entre "o estado de Exceção [, o Estado de sítio] e a relação de inimizade tornaram-se a base normativa do direito de matar" (Mbembe, 2018, p. 127). Ou seja, cria-se um clima de que 'o inimigo está próximo e preciso me defender'. Assim, "é nesse espaço de dúvida, paranoia, loucura que o modelo colonial de terror se impõe. A iminência da guerra, a emergência de um conflito e o estresse absoluto dão a

\footnotetext{
${ }^{8}$ Sob a ótica de Ferreira (2014) o colonialismo tornar-se-ia um operador estratégico de uma fração da produção das ciências sociais (como ocorreu na antropologia) e, nos últimos anos, especialmente entre aquela denominada "estudos pós-coloniais". Entretanto, a abordagem dos estudos pós-coloniais e suas flexões críticas (como os da colonialidade dos saberes) encontram determinados impasses derivados exatamente do paradoxo da teoria anticolonial, que é fruto de uma determinada política anticolonial/teoria da revolução. Essa política anticolonial foi produzida numa tensão interna à teoria e ao movimento social (no sentido amplo) entre o nacionalismo e o internacionalismo e entre as teorias anarquista, social-democrata/comunista e nacionalista da revolução.
} 
tônica para o mundo contemporâneo, em que a vida é subjugada ao poder da morte" (Mbembe, 2018, p. 34).

Almeida (2020, p. 120), complementa essa análise ao afirmar que quando o Estado assume o discurso de que "estamos em guerra" e o "inimigo está próximo" é o suficiente "para que sejam tomadas medidas excepcionais, tais como toques de recolher, 'mandados de busca coletivos', prisões para averiguação, invasão noturna de domicílios, destruição de imóveis, autos de resistência, etc.". Dentre os exemplos brasileiros mais ilustrativos da instauração na necropolítica está a "Guerra às Drogas", legitimada pelo Estado sob o escopo da Lei no 11.343 de 2006, mas em nome da qual, inumeráveis ações policiais que estão fora do escopo desta Lei podem ser tomadas pois estão sob o escopo do Estado de sítio / Estado de exceção. Sobre as vítimas da Guerra às Drogas, Rita von Hunt dedicou um vídeo inteiro para tratar especificamente da questão:

[simulando um pedido de drogas por telefone ela diz:] "Alô? Pronto! Isso... Dona Rita Von Hunt, a comunista! Sim... do 506, Alameda Santos, 27. Isso eu estou ligando para o meu "deeler" para comprar drogas! Drogas pesadas... ilícitas... $1 \mathrm{Kg}$ de cocaína, da farinha boa, sim, haxixe pode mandar... LSD vou querer sim, pode mandar... MD pode mandar que agora eu tenho amigas na The Week [uma boate], eu vou muito para Have. Esse aí pode mandar também, não sei... mas eu vou tomar tudo! Poppers, não precisa dessa vez que eu tô com uma coisa do prolapso horroroso, menina... Tá! Sim... e uma Sprite [refrigerante], por favor, que eu gosto de tomar com refrigerante. Tá, muito obrigada! Drogas pesadas, Alameda Santos, 27. Isso, do 506, obrigada".

Vamos lá embaixo que eu fiz o teste e parece que para ser preso a gente tem que ser preta, pobre, favelada e ir no baile funk. Então para gente tá tudo bem [a personagem é branca, de classe média e se veste com trajes formais, comumente usa tailleur].

Bom, como você já deve ter visto em algum local desta tela, o tema do vídeo de hoje é "Guerra às Drogas". Talvez seja bom que eu já começo dizendo que eu detesto esse termo porque ele mascara o que tá acontecendo de verdade e aqui, no Brasil, o que tá acontecendo de verdade é a institucionalização de uma prática para o encarceramento e o genocídio em massa da população negra e periférica e pobre do nosso país. Aliás, isso é tão explícito que às vezes até me parece bobo fazer um vídeo para falar sobre isso, né? Por exemplo, que a palavra TRA-FICAN-TE vai aparecendo conforme a cor da pele vai aparecendo, né? Conforme a gente tem uma marca étnica-racial, a palavra traficante magicamente aparece nas notícias. $E$ aí basta que a gente se lembre, por exemplo, de todas as vezes que o "ES-TU-DAN-TE de ME-DI-CI-NA é apreendido com entorpecente". Nunca é um traficante de drogas, porque você estuda medicina. [...] Lá nos anos 50, aqui para puxar a brasa para minha sardinha que sou Professora de Literatura, nos Estados Unidos a gente tem beat generation (geração beat), essa geração de artistas que ia na contramão que propunha a sociedade alternativa - um beijo Raul [Raul Seixas]. E, moçada, vocês sabem que, um desses expoentes lá nos Estados Unidos é o Burroughs. E o Burroughs, ele tem, Naked lunch, né, o almoço pelado, Junky, vários outros escritos... Esses são os mais famosos. E nesses escritos, nos anos 50, o Burroughs tá propondo aqui uma reflexão superinteressante, que é a seguinte: você e eu, amamos usar drogas. Você usa Lithium, Valium, Pozac[kium], Whisky[um], Rivotril[ium], Cigarr[ium]. Você usa várias drogas e as suas são legalizadas, e ninguém implica que você as gosta de usar. E por que as minhas estão proibidas? Hum? E o Burroughs tá levando essa guerra para essa fachada de moral e bons costumes que proíbe algumas drogas, ao passo que libera outras sem nenhum tipo de moral e bons costumes. O que a nossa "Guerra as Drogas" no Brasil faz é enriquecer quem faz vista grossa, né... para o comércio, para comercialização, para o narcotráfico, trazer uma violência inimaginável para as periferias da cidade e com balas perdidas, começar o genocídio dessa população. Esse ano uma série de crianças foi baleada em troca de tiroteio, em ação de invasão de comunidade por polícia, ou em PER-SE-GUI-ÇÃO de narcotraficante pela polícia, né? Aqui eu vou deixar alguns nomes porque eu acho importante que a gente carregue o peso de morar no Brasil. Agatha Félix tinha 8 anos foi brutalmente assassinada com uma bala perdida nas costas dentro de uma perua escolar. E eu peço agora que a gente talvez antes de continuar a discussão da "Guerra às 
Grogas" se pergunte: "o que teria acontecido se o filho de um juiz, no Jardim Europa, em São Paulo, tivesse tomado um tiro de uma bala perdida de um policial, nas costas, numa perua escolar no Jardim? Se o filho de um juiz, branco, rico, que que será que teria acontecido"? Cauã Ribeiro tinha 12 anos, Cauã Rosário tinha 11, Cauã Peixoto tinha 12 e Jennifer Silene Gomes tinha 11. Essas foram as vidas tiradas em nome à "Guerra às Drogas", ao combate ao narcotráfico, à proibição... E agora uma coisa "muito engraçada": a polícia entra na periferia, sobe o morro, atirando né? Ou então vamos mandar um beijo para o João Dória, Governador desse maravilhoso estado [São Paulo] que deu uma declaração que, a partir de Janeiro [ de 2019] a polícia ia atirar para matar ${ }^{9}$ e depois se disse "muito comovido", "muito pego de sobressalto", com a ação que tinha acontecido agora em Paraisópolis, quando a polícia CO-VARDE-MEN-TE, acuou e amontoou uma série de jovens que estavam no baile funk numa ruela, resultando em nove pessoas mortas, quase que por um tipo de soterramento humano ${ }^{10}$ (grifos nossos).

Rita von Hunt inicia o diálogo com seu público denunciando como a "Guerra às Drogas" somente é aplicável a quem é pobre e negro/a. Além disso, essa "guerra" não é exatamente contra as drogas. É contra o povo negro e pobre. Isto porque "Lithium, Valium, Pozac[kium], Whisky[um], Rivotril[ium], Cigarr[ium]" são drogas com alto potencial à dependência química e são legalizadas. Além disso, segundo o Observatório do Terceiro Setor, o álcool mata 9 vezes mais que qualquer outra droga, inclusive as ilícitas (OBSERVATÓRIO DO TERCEIRO SETOR, 2017), mesmo assim, é uma droga legalizada e contra a qual não se deflagra guerra alguma. Essa "Guerra às Drogas" tem servido tão somente à justificação de abordagens policiais violentas, ao encarceramento em massa da população negra, bem como à execução de crianças, adolescentes e jovens negros/as pela mão do Estado.

Os exemplos citados por Rita von Hunt de Ágatha Félix (08 anos), Cauã Ribeiro (12 anos), Cauã Rosário (11 anos), Cauã Peixoto (11 anos) e Jennifer Silene (12 anos) são apenas ilustrativos na necropolítica perpetrada pelo Estado brasileiro. Poderíamos nos indagar se o encarceramento dos policiais ou dos traficantes que dispararam os tiros contra essas crianças impediria que outras crianças como elas fossem diuturnamente alvejadas por outras balas na "Guerra as Drogas"? As vidas desses infantes valem a "Guerra às Drogas"? Borges (2020) afirma que "o discurso de epidemia e de amedrontamento da população em relação às substâncias ilícitas cria o caldo necessário para a militarização de territórios periféricos sob o verniz de enfrentamento a esse 'problema' social" (Borges, 2020, p. 23).

Após a Lei de Drogas, o Estado brasileiro vive um hiperencarceramento dos jovens negros e o tráfico lidera "as tipificações" (Borges, 2020, p. 24). Com efeito, essas pessoas encarceradas não são os grandes traficantes e tampouco seu encarceramento impede, ou sequer, limita o tráfico de drogas ilícitas. Basta recordar do caso dos "Jovens de bairros nobres de SP [que] são presos suspeitos de traficar 'geleia de maconha' em festas universitárias e por redes sociais" (G1, 2021, online). Trata-se do caso de 10 jovens de bairros de classe média alta da cidade de São Paulo que eram investigados pelo Departamento Estadual de Prevenção e Repressão ao Narcotráfico (Denarc) da Polícia Militar do Estado de São Paulo, que tiveram suas casas revistadas por meio do cumprimento de 36 mandados de busca e apreensão; e que, com eles, além, da geleia de maconha, foram encontrados ecstasy, cocaína e haxixe. As drogas eram vendidas em sites de redes sociais para outros jovens de classe média alta em festas universitárias fechadas (já que as aglomerações estavam proibidas naquele período). Nesta ação, das dez pessoas que foram detidas, sete ainda 
estavam privadas de liberdade no momento da publicação da matéria, mas "as outras três acabaram soltas pela polícia para responderem ao mesmo crime em liberdade" (G1, 2021, online).

Será que se a apreensão da mesma quantidade de drogas se desse numa favela, o cuidado para o acesso às residências via mandado de busca e apreensão seria o mesmo? Será que seriam tratados pelos veículos de mídia como "jovens", ou "suspeitos"? Será que os "jovens" teriam seus nomes preservados, como o foram? Nessa mesma direção, podemos apontar caso ocorrido em 21 de fevereiro de 2020, no qual um "estudante de medicina" de 29 anos, foi apreendido pela Polícia Federal brasileira em Santa Terezinha de Itaipu-PR, com $42 \mathrm{~kg}$ de cocaína e $16 \mathrm{~kg}$ de crack, escondidas em seu carro quando dirigia na rodovia BR-277 em direção a São Paulo-SP. Em toda a narrativa, a matéria do G1 o trata como "suspeito", como "estudante", mas não só não divulga seu nome como também nunca o adjetiva como "criminoso" (G1, 2020).

Com relação ao encarceramento e o genocídio do povo negro, no contexto da sociedade capitalista, esses, enquanto mercadorias, assumem valor de uso e valor de troca Um dos exemplos mais ilustrativos disso são os "programas policiais", exibidos mais ou menos ao meio dia. Esses, ao mesmo tempo em que utilizam seus espaços na mídia televisiva para propagandear o encarceramento e as execuções do povo negro e pobre, fazem o que, de fato, estão ali para fazer: propagandas pagas de todos os tipos de mercadorias, desde cestas natalinas até planos funerários. Narrativas burlescas como essas, mesmo que veiculadas por empresas privadas de comunicação, no Brasil, só são possíveis com o aval do Estado porque é esse que detém o poder de conceder espaços no Rádio e na TV a empresas privadas que, além de produzirem seus lucros com propagandas, contribuem para a manutenção do ideário hegemônico de Francis Fukuyama de que o capitalismo é a forma mais bem acabada de sociabilidade e que não há futuro para além do Capital (Fukuyama, 1989, 1992). O resultado dessa confluência de forças ideológicas e materiais reforçam o estereótipo do/a negro/a como um/a sujeito/a perigoso/a ou criminoso/a (em potência ou em ato). Esses são ingredientes suficientes para a fermentação do medo e do ódio na população, inclusive na população negra e pobre, contra o próprio povo negro e pobre. As forças ideológicas do Estado racista forjam as consciências no sentido de criar uma imagem, um estereótipo da figura do/a criminoso/a. Essa imagem, por sua vez, é também uma imagem racista.

É diante de dados como esses que Rita von Hunt nos provoca à reflexão a partir das seguintes indagações:

por que é que a polícia entra atirando ou não entra com essa ação violenta, forte, corajosa, em have? Sim, né? Porque a gente sabe que uma have é uma festa de música eletrônica que dura $28,36,42$ horas e nem um corpo de um ser humano dança esse tempo se não tiver sobre efeito de fortes psicotrópicos. Será que não tem consumo de drogas nas festas da Mackenzie [universidade privada de elite]? Da PUC [universidade privada de elite]? Da USP [universidade pública de elite]? Será que não tem consumo de drogas na festa do peão de Barretos [festa sertaneja de elite]? Será que não tem consumo de drogas no Vila Country [evento sertanejo de elite], no Vila Mix [evento sertanejo de elite]? Será que não tem consumo de drogas na The Week [boate de classe média alta]? Mas por que que será que a polícia só entra atirando para matar, com bala perdida, com criança, com soterramento, na favela? (Guerra às Drogas, 2019)

Os exemplos das festas citadas por Rita von Hunt tem um elemento em comum: todas são destinadas à classe média branca, ao contrário dos bailes funks que são destinados ao povo pobre negro e favelado. A polícia não invade qualquer festa, em qualquer lugar, na qual esteja qualquer público. A mão armada do Estado só invade os espaços nos quais a necropolítica vai atuar, ou seja, as periferias e favelas. Com efeito, para obter o apoio popular nessas investidas, ou seja, para a formação ideológica da figura do criminoso (em potencial ou em ato), os veículos de mídia de massa cumprem um papel decisivo e somente quando a ideologia não dá conta, o encarceramento e a morte, entram em ação. Além disso é preciso ter clareza de que, a própria dependência química é 
reflexo das condições objetivas as quais as pessoas são asujeitadas. Rita von Hunt, ao rememorar a revisão do experimento do Pesquisador e Psicólogo da Universidade de Vancouver, Bruce Alexander, vai afirmar que quando os ratos são

postos em gaiolas com muitos amigos, alta disponibilidade de sexo, muitas distrações e enriquecimento ambiental, eles vão ter bolinha colorida, ração, estopa, túneis, "água sem batizar" [água potável] e "água batizada" [água com drogas psicoativas]. O número [...] [de ratos] morrendo por overdose cai para um número próximo à zero. Então os ratos que estão nessa gaiola com amigos, companhia, distração, comida, oferta de amizade, sexo, vida em comunidade, NÃO USAM A DROGA e quando a usam, A USAM DE FORMA RECREATIVA sem overdose. Desde os anos 70 a gente sabe que o que vicia, o que torna as pessoas viciadas, não é exatamente uma postura criminal e nem o entorpecente em questão, mas A GAIOLA NA QUAL A GENTE ESTÁ PRESO. [...] A gente deveria olhar para essas pessoas como pessoas que estão em gaiolas que as deixam tristes (Guerra às Drogas, 2019)

Além do estudo de Bruce Alexander, Rita von Hunt vai citar um outro estudo do pesquisador holandês Peter Cowen:

ele pede que a gente, no estudo dele, pare de usar a palavra ou o entendimento ou a ideia de VíclO, de dependência e comece a pensar que o ser humano constrói laços e esses laços são construídos com outras pessoas, com coisas ou com práticas. O problema é que na falta da possibilidade de criar laços sadios, o que sobra para esses seres humanos que estão presos em gaiolas tristes é a única possibilidade de criar laços de dependência com entorpecentes, com substâncias que fazem mal. E para que a gente aproxime esse estudo ou essa ideia da gente, é só pensar em você que tá vendo vídeo [na verdade, que está lendo este artigo] e está, por exemplo, com uma garrafinha de água com você. Vodka é legalizada! E por que ao invés de água nessa garrafinha, você não tem vodka? E por que ao invés de suco, chá, açaí, você não toma vodka com todas as refeições? Provavelmente a resposta na qual você vai chegar é que você não faz isso, porque você não precisa, não quer e não depende disso para nada. (Guerra às Drogas, 2019).

Rita acrescenta que, se o Brasil, de fato, quisesse promover um enfrentamento às mazelas do vício em drogas ilícitas, teria feito como Portugal:

A partir de um painel liderado por um médico chamado Dr. João Goulão os portugueses chegaram à conclusão de que a melhor alternativa seria a legalização de TODAS as drogas, de cannabis a crack. Com a regra de que o dinheiro que era antes usado numa proposta "Guerra às Drogas" ou na recuperação, quase sempre que não surte efeito, dessas pessoas viciadas, fosse agora investido na INSERÇÃO REAL DESSAS PESSOAS NA SOCIEDADE; criação de empregos estáveis para essas pessoas; ou microcréditos para que elas pudessem abrir seus próprios negócios. Depois de 15 anos, segundo o British Journal of Criminology, Portugal viu os índices de drogas injetáveis caindo por $50 \%$. Uma queda estarrecedora da infecção por HIV, da overdose e de crimes cometidos por pessoas que queriam usar drogas como fruto dos seus furtos ou vendas ou etc. $O$ que está posto pelos nossos irmãos portugueses é que depois de 15 anos de investimento público consciente para integrar pessoas em sociedades, tirando elas das suas gaiolas tristes e fazendo com que elas tivessem expectativas reais e razões para acordarem e laços saudáveis, o problema com as drogas e com a "Guerra às Drogas" foi praticamente extinto em Portugal (Guerra às Drogas, 2019).

A questão é que a Lei de Drogas não impede o aumento da dependência química de drogas ilícitas, não combate efetivamente o tráfico, e tampouco produz uma sociedade melhor. O que a Lei de Drogas produz é uma Guerra, mas não contra as Drogas. Produz uma guerra sobretudo contra a infância e a juventude negra, pobre e favelada que diuturnamente é encarcerada e morta no fogo cruzado entre policiais e traficantes. No vídeo "Racismo, coisa de branco" Rita von Hunt recupera a 
crítica à "Guerra às Drogas" e enfatiza que nesta necropolítica, cada vez mais, mais crianças têm sido mortas pelas balas perdidas que sempre encontram um corpo negro, pobre e favelado para alvejar:

Quando a gente pensa, por exemplo, na violência Estatal e em todas as crianças pretas que foram assassinadas pelo Estado e a gente consegue lembrar da Agatha Félix ${ }^{11}$ que tomou um tiro nas costas enquanto voltava da escola uma perua; ou Marcos Vinícius ${ }^{12}$, né..., na "comunidade da Maré" que tomou um tiro com uniforme da escola e antes de morrer ele falou para mãe: "eles não viram que eu tava de uniforme"? Né? Mas o Estado não viu isso! Aliás, o Estado no Rio de Janeiro-RJ tem essa engraçada... é... circunstância de que ele confunde parafuzadeira com pistola, guarda-chuva com metralhadora, o carro de uma família com o carro dos Irmãos Metralha, né? O Estado do Rio de Janeiro-RJ tem uma espécie de miopia racial que se o alvo do tiro foi uma pessoa preta... nossa... Ele já não sabe mais o que estão vendo! Ou a gente pode falar do caso do João Pedro ${ }^{13}$ que, enquanto cumpria a quarentena dentro de casa, teve a casa dele alvejada por tiros. Um dos tiros o atingiu. A polícia tira esse menino de casa e depois desova o corpo dele no IML [Instituto Médico Legal]. E aí você não tá entendendo a dimensão ou problema ou a urgência disso, na semana passada depois da terça-feira onde todo mundo colocou uma imagem em preto no seu feed com a hashtag \#blackoutthursday, né? Que falaram que iam se educar, se instruir... na quinta-feira, a gente fica sabendo do caso do menino Miguel $^{14}$. Aliás, vale lembrar que isso foi no mesmo dia que aquela "blogueira lixo", a Flávia Nunes, disse que o racismo é natural; que é natural pessoas brancas terem medo de pessoas pretas, porque as pessoas pretas naturalmente, cometem mais crimes. Dá vontade de explodir a própria cabeça, né? Eu nunca vou me esquecer dessa quinta-feira porque eu tinha acordado, né? O que nesse Brasil não é simples, e eu estava começando a me preparar para trabalhar normalmente. Às quintas-feiras eu gravo os vídeos do "Tempero" [Canal Tempero Drag]. Nesse dia, também eu ia dar uma entrevista para "Sky" e gravar um outro vídeo de um outro trabalho. Era de manhã e eu recebi uma mensagem com a notícia. Depois de ler aquela notícia, eu não tinha mais nada humano dentro de mim para continuar aquele dia. Eu cancelei todos os meus compromissos. Eu voltei para cama e eu tentei fingir que eu não existia, que eu não morava no Brasil, que eu não estava vivendo essa realidade. $\mathbf{O}$ assassinato do menino Miguel, ele é um caso que está repleto de racismo [...] dessa elite branca, que abusa do seu poder porque sabe que nada vai acontecer com ela além de corrupção, né... bom, se você estava em outro planeta, ou se você não ligou para o caso, pra entender ele a gente pode ir por partes: primeiro que esse assassinato [o do menino Miguel, de 5 anos de idade] acontece em Recife-PE, numa parte Nobre da cidade, no Cais de Santa Rita. Aliás, vale lembrar: uma área tombada pelo Patrimônio Histórico da cidade, né? Que "magicamente" com a ajudinha de alguém do STJ [Supremo Tribunal de Justiça], com um advogado esquisito, né... com uma licitação mágica... com uma empreiteira de nome estrangeiro... eu tô deixando a notícia na descrição [descrição do vídeo] para você ler e se apavorar com o que tá acontecendo. Ou então você pode assistir Aquários ${ }^{15}$. Lembra desse filme nacional? Ele é exatamente sobre isso! Sobre uma mágica que estava acontecendo no Recife-PE que, de repente, áreas que não podiam ter torres gigantescas imobiliárias, de frente pra o mar, estavam fazendo milhões com especulação financeira. Nossa... por que será? Para piorar, né, o cenário que parece uma piada, aliás tudo que envolve essa elite nojenta, racista, filha do Bolsonaro ${ }^{16}$, parece uma piada de mau gosto. Essas duas torres são

\footnotetext{
${ }^{11}$ Disponível em: https://brasil.elpais.com/brasil/2019/11/19/politica/1574171033 166751.html

12 Disponível em: https://extra.globo.com/casos-de-policia/antes-de-morrer-adolescente-baleado-na-mare-disse-paramae-que-tiros-partiram-de-caveirao-22807752.html

13 Disponível em: https://brasil.elpais.com/sociedade/2020-05-19/jovem-de-14-anos-e-morto-durante-acao-policialno-rio-e-familia-fica-horas-sem-saber-seu-paradeiro.html

${ }^{14}$ Disponível em: https://www.bbc.com/portuguese/brasil-52932110

${ }^{15}$ Aquarius.(2016) Direção: Kleber Mendonça Filho. Brasil/França, Pernambuco: Vitrine Filmes (Brasil) e Vitagraph Films (Estados Unidos): (145 min)

${ }^{16}$ A referência é a Jair Messias Bolsonaro (Sem Partido), Presidente do Brasil eleito em 2018.
} 
conhecidas como as "Torres Gêmeas". E aí o show de horrores continua tá... Você precisa saber que esse rapaz Sérgio Hacker Corte-Real, que é prefeito de Tamandaré-PE, mas ele não mora na cidade onde ele é Prefeito, parece Bacurau ${ }^{17}$, né? Nossa, como a arte imita a vida... Bom... esse corrupto, esse nojento, esse crápula, esse salafrário, ele é casado, com a Sari Corte-Real, né? Essa linda dondoca branca europeia, né? Gente... igualzinho ao Bacurau, é essa gente nojenta que se acha branca e faz acordos com pessoas que matam a população do seu país! Bom, o Sérgio Hacker tinha uma funcionária que trabalhava dentro da casa dele, uma empregada doméstica. Aliás... por que que a gente tem tanta empregada doméstica no Brasil? Será um retrato de que a gente ainda sonha em ser uma sociedade escravagista, "eu não sei"... Engraçado a densidade do bizarro né, mas depois que brasileiros começaram a ir para Portugal, as construtoras em Portugal estão construindo apartamento com quarto de empregada, um negócio que não existia lá, mas a elite nojenta do Brasil que tá acostumada a ter a senzala anexada à casa grande sonha, né? Em ter o quartinho da empregada nos seus apartamentos. Bom, o Sérgio desviava dinheiro público, verba pública da Prefeitura e contratava a sua empregada doméstica com dinheiro desviado. Ela consta como uma funcionária da prefeitura, mas trabalha na casa dele. Tá absurdo suficiente? Não! Vai piorar... vai piorar muito! A Mirtes Renata Santana de Souza, mãe do menino Miguel, eu vou deixar para vocês adivinharem... ela teve seu salário garantido e pôde ficar em casa para fazer a sua quarentena ou ela foi obrigada a se expor ao vírus [Sars-Cov-2 - Patógeno responsável pela pandemia do COVID-19] e a trabalhar na casa da família? Nossa... nunca saberei o que esse emprego te quer. Depois de não ter a sua saúde e o seu salário, garantidos, né? E ser obrigada a trabalhar, a Mirtes que tem um filho pequeno Miguel o leva para o trabalho consigo. Essa é uma realidade muito comum das empregadas domésticas que vivem ou moram ou passam muito tempo nos seus empregos e não têm tempo para ficar com suas famílias. Fica como indicação "Que horas ela volta"18, se você ainda não assistiu esse filme. Forçada a trabalhar na Pandemia, impossibilitada de ficar com filho, levando o filho para emprego, a Mirtes depois de tá lá trabalhando onde ela não devia, no momento que ela não devia, ela recebe a ordem da Sari de levar o cachorro para passear. [...]. Enquanto a Mirtes atende às necessidades do cachorro da Sari, a Sari é incapaz de atender as necessidades do filho da Mirtes. Tem vídeos que vazaram das câmeras de segurança dos elevadores né? Desse menino desesperado procurando a mãe e da Sari muito ocupada fazendo a unha. Eu fico imaginando qual será a cor da mulher que estava fazendo a unha da Sari... bom mas isso não vem ao caso, né? "Casa-grande Senzala" ${ }^{19}$ ficou lá para trás. Aí, o que que acontece? A Sari coloca uma criança de 5 anos de idade dentro de um elevador e aperta para o nono andar porque ela não tem a intenção de matar... ela tá sendo processada por homicídio culposo onde não há dolo, né? A gente tem uma mulher adulta que coloca um bebê de 5 anos de idade sozinho dentro de um elevador e aperta no nono andar e ela não tem o dolo, ela não tem a vontade de matar essa criança. $O$ Miguel se soma ao nome de todas as outras crianças que eu falei aqui onde ele é vítima de uma política genocida e racista e agora não implementada pelo Estado, mas implementada por quem governa o Estado: a Esposa de um prefeito. Já terminou de ficar ruim? Não ainda vai piorar! Depois desse menino cair do nono andar e morrer e a Sari ser autuada em flagrante e ser levada para a delegacia, ela pagou uma fiança de $\mathrm{R} \$ 20.000,00$. E agora ela vai responder ao processo em liberdade. Justiça para quem? Será que tem um motivo para o nosso sistema de justiça ser conhecido como justiça burguesa? Por que se fosse o contrário? Se a empregada tivesse colocado o filho da patroa sozinho no elevador, apertado o nono andar, o filho da patroa tivesse morrido ela ia pagar a fiança e responder em liberdade? Ela ia ser processada por homicídio culposo? E tem esse fato curioso da Justiça no Brasil, né? Que a gente tem a terceira maior população penitenciária e ela é majoritariamente jovem negra e masculina. Também tem essa coisa mística da Justiça que

\footnotetext{
${ }^{17}$ Bacurau. (2019) Direção: Juliano Dornelles, Kleber Mendonça Filho. Pernambuco: Vitrine Filmes, (131min).

${ }^{18}$ Que horas ela volta? (2015) Direção: Anna Muylaert. Brasil: Pandora, 114 min

${ }^{19}$ Referência a obra: Freyre, Gilberto. (2019) “Casa-grande \& senzala”. Global Editora e Distribuidora Ltda.
} 
quando o filho do Eike Batista ${ }^{20}$ atropela um homem preto, pobre e periférico numa bicicleta e o mata, o filho do Eike Batista não vai preso ${ }^{21}$. Mas se um homem preto, pobre e periférico numa bicicleta tivesse matado o filho do Eike Batista, o que é que será que teria acontecido? (Racismo, coisa de branco, 2021, grifos nossos)

Neste excerto do vídeo, Rita von Hunt reitera as denúncias do encarceramento e do genocídio de crianças, adolescentes e jovens negros/as, pobres e periféricos/as. A protagonista do Canal "Tempero Drag", estabelece uma analogia da posição que mulheres como Sari Corte-Real ocupam na sociedade capitalista com a situação das senhoras de engenho da sociedade escravocrata. Se utilizando da mesma analogia, Rita von Hunt denuncia que a situação e a cor da pele das manicures ou as empregadas domésticas dessas "Senhoras da Casa Grande" comumente é negra; que essas mulheres da classe trabalhadora têm de se submeter a todo tipo de absurdo para poder sobreviver, inclusive deixando de cuidar de seus próprios filhos para cuidar das unhas ou mesmo do cachorro da dona da casa grande. Rita também denuncia que a Senzala onde essas mulheres moram comumente é muito distante das casas grandes nas quais empregam toda a sua força de trabalho.

Com efeito, ao dispor do aparato Estatal, o marido de Sari Corte-Real, que era Prefeito de Tamandaré-PE, mas morava na capital Recife-PE, pagava a Mirtes, sua empregada doméstica, com desvio de dinheiro público. Ou seja, a empregada doméstica da "Casa Grande" não era oficialmente empregada doméstica e sim, funcionária pública. Contudo, na prática, o único público que se beneficiava de seus serviços era o núcleo central da família do Prefeito de Tamandaré-PE, mais especificamente as pessoas que moravam em sua própria residência em Recife-PE. Essa prática de utilizar "funcionários fantasmas" 22 não é nenhuma novidade na realidade brasileira e tampouco na realidade mundial, uma vez que a corrupção não é endógena do Estado brasileiro ou mesmo dos países da periferia do capitalismo, como se pode constatar pelo mapeamento do Índice de Percepção da Corrupção, desenvolvido pela Organização Não-Governamental "Transparência Internacional"23. A corrupção é endógena do próprio capitalismo (DEMIER; HOEVELER, 2016).

Com efeito, a divulgação de matérias sobre a corrupção induz a população a construir a ideia de que essa está diretamente associada à coisa pública e por isso, melhor seria privatizar tudo. Essa é uma falácia aliada aos interesses do Estado de viés ideológico à direita ou à extrema direita. Tratase de um engodo que serve única e exclusivamente aos interesses do Capital mesmo que para isso o infanticídio negro e periférico, pelas mãos do Estado, cresça cada vez mais. Compreendemos que as ações de tônica revolucionária de Rita von Hunt buscam não só a crítica ao ideário capitalista, mas sobretudo a sua superação radical. Tal movimento, dentro do YouTube, só é possível porque, em algum grau, essa interface não pode cercear de todo a pluralidade de ideias. No entanto, mesmo sendo um dos maiores Canais de educação informal com potência revolucionária, os filtros dos algoritmos do YouTube determinam os limites de alcance da voz de Rita von Hunt. Contudo, não se

\footnotetext{
${ }^{20}$ Eike Batista é um empresário brasileiro, cujo ramo principal de negócios é o da exploração de combustíveis fósseis como petróleo, gás natural e carvão mineral. Figurou em 2012, segundo a Revista Forbes, como o brasileiro mais rico do mundo, com uma fortuna estimada em torno de US\$30 bilhões. Disponível em: https://exame.com/negocios/os10-brasileiros-mais-ricos-em-2012-segundo-a-forbes/

21 Disponível em: http://g1.globo.com/rio-de-janeiro/noticia/2012/03/filho-de-eike-batista-se-envolve-em-acidentecom-morte-no-rj-diz-policia.html

22 Disponível em: https://g1.globo.com/jornal-nacional/noticia/2020/08/18/funcionarios-fantasmas-da-alerj-seguemsem-punicao-oito-meses-apos-reportagem.ghtml

23 Segundo o site "transparência Internacional", o Índice de Percepção da Corrupção é o principal indicador de corrupção do mundo. Produzido desde 1995 pela Transparência Internacional, o IPC avalia 180 países e territórios e os atribui notas em uma escala entre 0 (quando o país é percebido como altamente corrupto) e 100 (quando o país é percebido como muito íntegro) $O$ índice é a referência mais utilizada no mundo por tomadores de decisão dos setores público e privado para avaliação de riscos e planejamento de suas ações. Disponível em: https://transparenciainternacional.org.br/ipc/
} 
pode desconsiderar que os vídeos do "Tempero Drag" podem favorecer a compreensão da realidade material e instrumentalizar a classe trabalhadora rumo a uma agitação social revolucionária.

\section{CONSIDERAÇÕES FINAIS}

Toda e qualquer forma de hierarquização humana por seus fenótipos não são outra coisa senão manifestações fenomênicas do racismo estrutural que alicerça a sociedade capitalista em seu conteúdo e em sua forma. O racismo, portanto, é estrutural e estruturante das relações sociais. Assim, não é ao acaso que as imagens das pessoas que aparecem como "criminosas" nos programas policiais, bem como as imagens daquelas que são vítimas das balas perdidas das polícias brasileiras, são, majoritariamente, negras/os. Isso quer dizer também que, o problema não é a instituição policial. O problema é a estrutura racista sobre a qual o Estado e suas instituições se erguem. Nas palavras de Rita von Hunt, o problema não é porque entre a água potável e a água batizada, os ratinhos optam pela água batizada. O problema é porque, numa gaiola na qual só se tem essas duas opções, para fugir das múltiplas formas de opressão que se apresentam nesta clausura, somente se sujeitando a água batizada para suportar a realidade objetiva massacrante que é viver nesta gaiola.

Compreendemos que, se sua voz conseguisse ecoar nas redes sociais da internet, se aglutinar com outras múltiplas vozes como as dela, e ganhar a capilaridade necessária junto a classe trabalhadora, teríamos as condições subjetivas necessárias para nos unirmos e, objetivamente, reunir as condições materiais para um levante das massas que, inevitavelmente, implodiria as bases do capitalismo. Constatamos que, pela via de uma educação informal, é possível identificar esforços de agitação social em favor de uma sociedade, na qual desejou Rosa Luxemburgo, "sejamos socialmente iguais, humanamente diferentes e totalmente livres".

A materialidade dos esforços de youtubers como Rita von Hunt somente são possíveis por meio de uma engenharia de subversão das finalidades do próprio ciberespaço, isto porque, sua finalidade não é fomentar uma formação anticapitalista, mas o contrário. É possível identificar, por exemplo, em meio às interfaces de compartilhamento de vídeos como YouTube, que geram lucros exorbitantes a partir de anúncios publicitários e contratos com outras empresas privadas e públicas, nichos que guardam potências revolucionárias no sentido dessa transformação social. Em outras palavras, é imprescindível que possamos, unidos/as, romper as grades da gaiola do capitalismo na qual estamos todos/as, cada vez mais, privados/as de dignidade humana.

A lógica mercantil e os algoritmos do YouTube são umas das principais limitações a passagem da potência revolucionária ao ato revolucionário de youtubers sérios/as engajados/as com a luta antirracista e que conseguem cooptar vultuosos números de seguidores/as. Com efeito, dentro da sociedade capitalista, o YouTube não poderia se manifestar de outra forma senão aquela que gera lucro. Assim, embora contenha inumeráveis nichos de potência revolucionária, dentro deste modelo de sociedade não existe alternativa para o YouTube se manter como uma das maiores plataformas de compartilhamento de vídeos do mundo, senão pelos algoritmos que priorizam o lucro. Para isso, se for necessário se valer dos dados dos usuários para melhor manipular o cardápio de vídeos que são oferecidos; se para prender a atenção dos/as usuários os conteúdos desses vídeos tiverem de fomentar o ódio e a inimizade; se a consequência, ou o objetivo, for forjar consciências aliadas à necropolítica estatal, então assim será feito. Não podemos suportar que o capitalismo avance sobre a humanidade e nos desumanize ainda mais.

Nenhuma transformação social é possível de ser realizada de forma individual. O "Mito do Super-Herói" que sozinho salva o mundo, precisa ser erradicado. Um belo exemplo disso é o caso de Martin Luther King. Segundo Davis (2018, p. 68) "nos Estados Unidos, mais de novecentas ruas levam seu nome em quarenta estados, na capital e em Porto Rico". Contudo, pesquisas do campo da geografia evidenciaram que as "práticas de nomeação sugeriram que elas têm sido adotadas para desviar a atenção de problemas sociais persistentes - a falta de escolas, de moradia, de 
empregos e o uso de estratégias carcerárias para ocultar a persistência desses problemas". Além disso, "mesmo que tenham sido escritos vários livros, tanto acadêmicos, quanto populares, sobre o papel das mulheres no boicote de 1955, King, que, na verdade, foi convidado para ser porta voz de um movimento quando era completamente desconhecido [...], continua sendo a figura dominante" (DAVIS, 2018, p. 69).

A tese que defendemos, à luz das análises do material produzido por Rita von Hunt (e toda a sua equipe de colaboradores e colaboradoras), é que, o YouTube, por meio de seus algoritmos, não é uma plataforma neutra e tampouco seu uso contribui para a construção de uma sociedade emancipada da mediação do dinheiro. Existem alternativas que se pretendem subversivas como é o caso do "Tempero Drag". Mas isso tem um limite: "o limite do terceiro vídeo sugerido pela plataforma". Além das necessidades objetivas mais imediatas (tais como alimentação, moradia, saúde, educação, e alhures) a classe trabalhadora, mesmo aquela portadora de smartfones com telas touch screen, no cenário atual, segue impedida de acessar os bens materiais que ela mesma produz. Seja porque não possui dinheiro para acessar a tais bens, seja porque, do ponto de vista dos melhores recursos do YouTube, os algoritmos encaminham as massas para que se conformem com seu lugar de subalternidade na pirâmide social deste modo de produção. Assim, o povo é alijado dos bens culturais que são produzidos nesta sociedade, dentre os quais aqueles vídeos disponíveis no YouTube que podem contribuir para a elevação das consciências.

Tudo o que, em termos estéticos, de melhor a sociedade produz(iu), é negado aos filhos e filhas da classe trabalhadora. Ao povo resta um entretenimento vazio, que contribui significativamente para um vácuo cognitivo que os/as reduz à impotência racional e que lhes impede de tomar consciência do que lhes oprime, Ihes animaliza ou lhes coisifica, minando qualquer possibilidade de levante popular rumo à transformação social, rumo a uma sociedade igualitária, rumo a uma sociedade emancipada. $O$ estado de letargia que algoritimos do YouTube conduzem os/as usuários/as também se constitui numa manobra necessária à reprodução do capitalismo, pois privam os/as filhos/as da classe trabalhadora daquilo que de melhor se produz e se disponibiliza nesta interface e o que resta é a fuga da realidade material favorecendo assim, a manutenção do status quo vigente.

Se os povos negros brasileiros, sobretudo os jovens negros, são obrigados a conviver num Estado racista sob a égide da necropolítica, com abordagens policiais truculentas, violadoras de direitos humanos, sob a sombra da morte; se essas e esses/as jovens negras/os são um dos principais alvos das mortes violentas intencionais e sobretudo das mortes por ação policial, como é que se espera que essa juventude reaja diante desse Estado que fomenta o ódio e a inimizade contra quem não é branco? Neste sentido, a interseccionalidade das identidades não é suficiente para nos permitir construir, do ponto de vista material e subjetivo, uma sociedade igualitária. Para isso, as lutas não podem mais ser fragmentadas [luta do movimento negro, luta do movimento gay, luta do movimento de lésbicas, lutas das pessoas transsexuais/travestis, luta pela legalização da Maconha (Canabis Sativa), luta antimanicomial, luta pela reforma agrária, luta do povo indígena pela proteção das reservas que ainda lhes restam, luta do movimento abolicionista prisional, etc.]. Somente pela unidade na diversidade, ou seja, somente pela via da interseccionalidade das lutas é que poderemos alçar vitórias significativas rumo a uma sociedade igualitária, livre e emancipada.

Contribuições dos Autores: da Silva, I. P.: concepção e desenho, aquisição de dados, análise e interpretação dos dados, redação do artigo, revisão crítica relevante do conteúdo intelectual; de Lira, M. T. V.: concepção e desenho, aquisição de dados, análise e interpretação dos dados, redação do artigo, revisão crítica relevante do conteúdo intelectual; Voss, L. K. A. F.: concepção e desenho, aquisição de dados, análise e interpretação dos dados, redação do artigo, revisão crítica relevante do conteúdo intelectual. Todos os autores leram e aprovaram a versão final do manuscrito.

Aprovação Ética: Não aplicável.

Agradecimentos: Não aplicável. 


\section{REFERÊNCIAS}

Akotirene, C. (2020). Interseccionalidade. São Paulo: Editora Jandaíra.

Almeida, S. L. (2020). Racismo estrutural. São Paulo: Editora Jandaíra.

Anuário Brasileiro de Segurança Pública. (2021) 15 Anuário Brasileiro de Segurança Pública. Fórum Brasileiro de Segurança Pública.

Borges, J. (2020). Encarceramento em massa. São Paulo: Sueli Carneiro ; Editora Jandaíra.

Bruno, A. (2014). Educação formal, não formal e informal: da trilogia aos cruzamentos, dos hibridismos a outros contributos. Medi@ções, 2(2), 10-25.

Carta Capital. (2021) Canais de extrema-direita receberam $\mathrm{R} \$$ 5,6 milhões do YouTube: os canais incentivaram atos antidemocráticos e publicaram vídeos atacando o STF e o Congresso Nacional. Disponível em:

https://www.cartacapital.com.br/cartaexpressa/canais-de-extrema-direita-receberam-r-56-milhoes-do-youtube/

Cerqueira, D.(2021) Atlas da Violência 2021. São Paulo: Ipea / FBSP / IJSN

Crenshaw, K. (2002) Documento para o encontro de especialistas em aspectos da discriminação racial relativos ao gênero. Revista estudos feministas, 10, 171-188. https://doi.org/10.1590/S0104-026X2002000100011

Davis, A. (2018). A liberdade é uma luta constante. São Paulo: Boitempo.

Davis, A. (2016). Mulheres, Raça e Classe. São Paulo: Boitempo.

Demier, F., \& Hoeveler, R. (orgs.) (2016). A onda conservadora: ensaios sobre os atuais tempos sombrios no Brasil. Rio de Janeiro: Mauad.

Ende, L. B., \& Oliveira, R. S. (2020). Atuação de algoritmos no direcionamento de conteúdo na internet: oportunidades de violação à democracia e a direitos fundamentais? Revista llustração, 1(1), 19-28.

Engels, F. \& Marx, K. (2007). A ideologia alemã. São Paulo: Boitempo.

Ferreira, A. C. (2014) Colonialismo, capitalismo e segmentaridade: nacionalismo e internacionalismo na teoria e política anticolonial e pós-colonial. Sociedade e Estado, 29(1), 255-288. https://doi.org/10.1590/S0102$\underline{69922014000100013}$

Fukuyama, F. (1992). O fim da história e o último homem. Rio de Janeiro: Rocco.

Fukuyama, F. (1989). The end of history?. The national interest, 16, 3-18.

G1. (2020). Estudante de medicina é preso com 42 kg de cocaína e 16 kg de crack escondidos em carro na BR-277, diz PRF: segundo a polícia, o suspeito disse que levaria a droga para São Paulo. Droga estava no painel do veículo, em Santa Terezinha de Itaipu. Disponível em: https://g1.globo.com/pr/oeste-sudoeste/noticia/2020/02/21/estudante-demedicina-e-preso-com-42-kg-de-cocaina-e-16-kg-de-crack-escondidos-em-carro-na-br-277-diz-prf.ghtml

G1. (2021). Jovens de bairros nobres de SP são presos suspeitos de traficar 'geleia de maconha' em festas universitárias e por redes sociais": dez pessoas foram detidas na terça (28) pela Polícia Civil em operação contra tráfico de drogas na capital e região metropolitana. Alguns dos suspeitos foram presos em Higienópolis, Perdizes e Pinheiros. Também foram apreendidos ecstasy, cocaína e haxixe e R\$ 10 mil. Disponível em: https://g1.globo.com/sp/sao-paulo/noticia/2021/09/29/jovens-de-bairros-nobres-de-sp-sao-presos-suspeitos-detraficar-geleia-de-maconha-em-festas-universitarias-e-por-redes-sociais.ghtml

Mbembe, A. (2018). Necropolítica. São Paulo: N-1.

O dilema das redes. (2020). Diretor: Jeff Orlowski. Streaming. Documentário. Netflix, (94 min)

Observatório do Terceiro Setor. (2017). Álcool mata 9 vezes mais do que drogas ilícitas. Disponível em: https://observatorio3setor.org.br/noticias/alcool-mata-9-vezes-mais-que-drogas-ilicitas/

Reich, W. (2001). Psicologia de Massas do Fascismo. São Paulo: Martins Fontes.

Reis, R., Zanetti, D., \& Frizzera, L. (2020). A conveniência dos algoritmos. Compolítica, 10(1), 35-58.

Sued, G. (2020). El algoritmo de YouTube y la desinformación sobre vacunas durante la pandemia de COVID-19. Chasqui: Revista Latinoamericana de Comunicación, 145, 163-180.

Teixeira, A. B., Silva, A. M., \& Figueiredo, Â. (2017). Um diálogo decolonial na colonial cidade de Cachoeira/BA: entrevista com Ochy Curiel. Cadernos de Gênero e Diversidade, 3(4), 106-120. 
The Intercept Brasil. (2019). Cinco dos dez canais que explodiram no ranking do youtube durante as eleições são de extrema direita: análise inédita mostra que algoritmo do Google ajudou bolsonaristas irrelevantes a bombarem durante as eleições. Disponível em: https://theintercept.com/2019/08/28/ranking-youtube-extrema-direita/ UOL. (2021) Canais que estimularam atos antidemocráticos receberam $\mathrm{R} \$$ 5,6 mi do YouTube. Disponível em: https://noticias.uol.com.br/politica/ultimas-noticias/2021/06/16/canais-atos-antidemocraticos-monetizacaoyoutube.htm

Recebido: 3 de outubro de 2021 | Aceito: 12 de janeiro de 2022 | Publicado: 24 de fevereiro de 2022

This is an Open Access article distributed under the terms of the Creative Commons Attribution License, which permits unrestricted use, distribution, and reproduction in any medium, provided the original work is properly cited. 